\begin{tabular}{|l|l|l||}
\hline \multicolumn{2}{|c|}{ PublisherInfo } \\
\hline \hline PublisherName & $:$ & Palgrave Macmillan UK \\
\hline \hline PublisherLocation & $:$ & London \\
\hline \hline PublisherImprintName & $:$ & Palgrave Macmillan \\
\hline
\end{tabular}

\title{
Comparing ONS's retail sales index with the BRC's retail sales monitor
}

\begin{tabular}{|c|}
\hline ArticleInfo \\
\hline 10.1057/palgrave.elmr.1410060 \\
\hline Feature \\
\hline 47 \\
\hline 49 \\
\hline RegistrationDate : $2007-4-20$ \\
\hline OnlineDate \\
\hline Crown copyright 2007 \\
\hline
\end{tabular}


Nicholas Palmer, ${ }^{\text {Aff1 }}$

Joscelyne Hynard, Aff2

Aff1 Office for National Statistics

Aff2 British Retail Consortium

\section{Examines the key indicators of retail sales growth and summarises important differences between them.}

This article compares two key indicators of retail sales growth, the Office for National Statistics' (ONS) retail sales index (RSI) and the retail sales monitor produced by the British Retail Consortium (BRC)in conjunction with KPMG. It is also an update of the joint ONS-BRC articles published by the BRC in spring 2003 and November 2006.

The two series are regularly quoted by the media and are used widely by retailers and retail analysts. Also, they both feature in the Bank of England's Inflation Report in its assessment of domestic demand and in the discussions of the Bank's MonetaryPolicy Committee.

There are some important differences between the two indicators in relation to coverage and the method of compilation, and these can sometimes lead to apparent discrepancies in the published figures. This article summarises those differences andcompares the headline BRC series with an estimated RSI series based on the panel of contributors used by the BRC.

Misc

The Full Text of this article can be found on the National Statistics website (http://www.statistics.gov.uk/elmr/04_07/downloads/ELMR_April07_Palmer.pdf). 